\title{
Triggering of major eruptions recorded by actively forming cumulates
}

SUBJECT AREAS:

GEOCHEMISTRY

PETROLOGY

SOLID EARTH SCIENCES

VOLCANOLOGY

Received

15 August 2012

Accepted

17 September 2012

Published

12 October 2012

Correspondence and requests for materials should be addressed to

R.N.T. (rex@noc.

soton.ac.uk)

* Current address:

Department of Earth

Sciences, Oxford OX 1

3AN, U.K.
Michael J. Stock*, Rex N. Taylor \& Thomas M. Gernon

National Oceanography Centre, Southampton, University of Southampton, Southampton SO1 4 3ZH, U.K.

Major overturn within a magma chamber can bring together felsic and mafic magmas, prompting de-volatilisation and acting as the driver for Plinian eruptions. Until now identification of mixing has been limited to analysis of lavas or individual crystals ejected during eruptions. We have recovered partially developed cumulate material ('live' cumulate mush) from pyroclastic deposits of major eruptions on Tenerife. These samples represent "frozen" clumps of diverse crystalline deposits from all levels in the developing reservoir, which are permeated with the final magma immediately before eruptions. Such events therefore record the complete disintegration of the magma chamber, leading to caldera collapse. Chemical variation across developing cumulus crystals records changes in melt composition. Apart from fluctuations reflecting periodic influxes of mafic melt, crystal edges consistently record the presence of more felsic magmas. The prevalence of this felsic liquid implies it was able to infiltrate the entire cumulate pile immediately before each eruption.

T he Las Cañadas volcano on Tenerife, Canary Islands, generated at least seven major explosive eruptions during the Quaternary ${ }^{1-3}$. These events resulted in widespread deposition of pyroclastic material, with an estimated volume of $>130 \mathrm{~km}^{3}$ (ref. 1,4). Despite considerable scientific interest in the volcano and associated hazards including major landslides ${ }^{5}$, little is known about the triggers for these large-scale events ${ }^{6}$. Early eruptions $(\sim 2 \mathrm{Ma})$ involved the explosive ejection of large volumes of phonolite magma, implosion of the volcanic edifice and development of the $16 \mathrm{~km}$ wide Las Cañadas caldera ${ }^{1}$. Products of this explosive phase are preserved within the caldera wall and the extensive pyroclastic apron of the Bandas del Sur (Fig. 1). More than seven ignimbrite units occur within the apron, each recording a separate Plinian eruption that culminated in a caldera collapse event ${ }^{1}$. Trachytes and phonolites of the Teide-Pico Viejo complex provide evidence that felsic magma remains beneath the centre of Tenerife ${ }^{3,5}$.

We have identified crystal cumulate nodules in ignimbrites from three major explosive eruptions: Fasnia, Poris and La Caleta ${ }^{1}$. Their distribution is laterally and stratigraphically variable within ignimbrite units, likely as a result of complex pyroclastic processes. These cumulates were not completely solidified before each eruption, and retain layers containing abundant inter-cumulus melt $<1 \mathrm{~cm}$ thick. Similar examples of crystal mush have been recorded from other effusive ${ }^{7}$ and explosive ${ }^{8}$ eruptions. However, here we use the 'live' cumulate nodules from Tenerife as a tool to examine the repeating magmatic processes that occurred prior to explosive volcanic eruptions. We present major and trace element chemical profiles across cumulate crystals to examine the magmatic processes that occurred during the development of the compositionally stratified magma chamber ${ }^{9}$, particularly during the final stages prior to eruption ${ }^{10,11}$.

Each of the mafic nodules contains medium-coarse grained cumulate crystals that are either in grain boundary contact as an adcumulate texture, or are partially separated by layers or domains rich in a microcrystalline, glassy groundmass. These melt-rich domains are bounded by crystalline layers and are quenched upon ejection from the magma chamber. As such, these nodules trap and have preserved the final liquid in contact with the cumulate which was actively forming at the margins of the magma chamber. It is the presence of discrete layers containing up to $80 \%$ interstitial melt that sets these apart from regular cumulates.

The most mafic nodules are wherlites, taken to represent material close to the chamber floor. Successively higher layers in the system are represented by gabbro, hornblende gabbro and foid gabbro to syenite. Within the gabbroic nodules, plagioclase $\left(\mathrm{An}_{50-88}\right)$ is more primitive (mafic) than individual crystals in juvenile pumice from the same eruption ${ }^{6}$. Well-defined core regions occur within many cumulus plagioclases and are overgrown by oscillatory or simple zoned mantles, occasionally with well-developed sieve textures. Clinopyroxene compositions are comparatively limited, ranging $\mathrm{En}_{31-42} \mathrm{Fs}_{12-19} \mathrm{Wo}_{46-50}$, similar to, or slightly more $\mathrm{Mg}$-rich, than those in juvenile pumice ${ }^{6}$. Typically, they have defined cores, with multiple and oscillatory zoned overgrowth mantles. Grain boundaries are generally well preserved, particularly in layers where the cumulus phases are separated by 

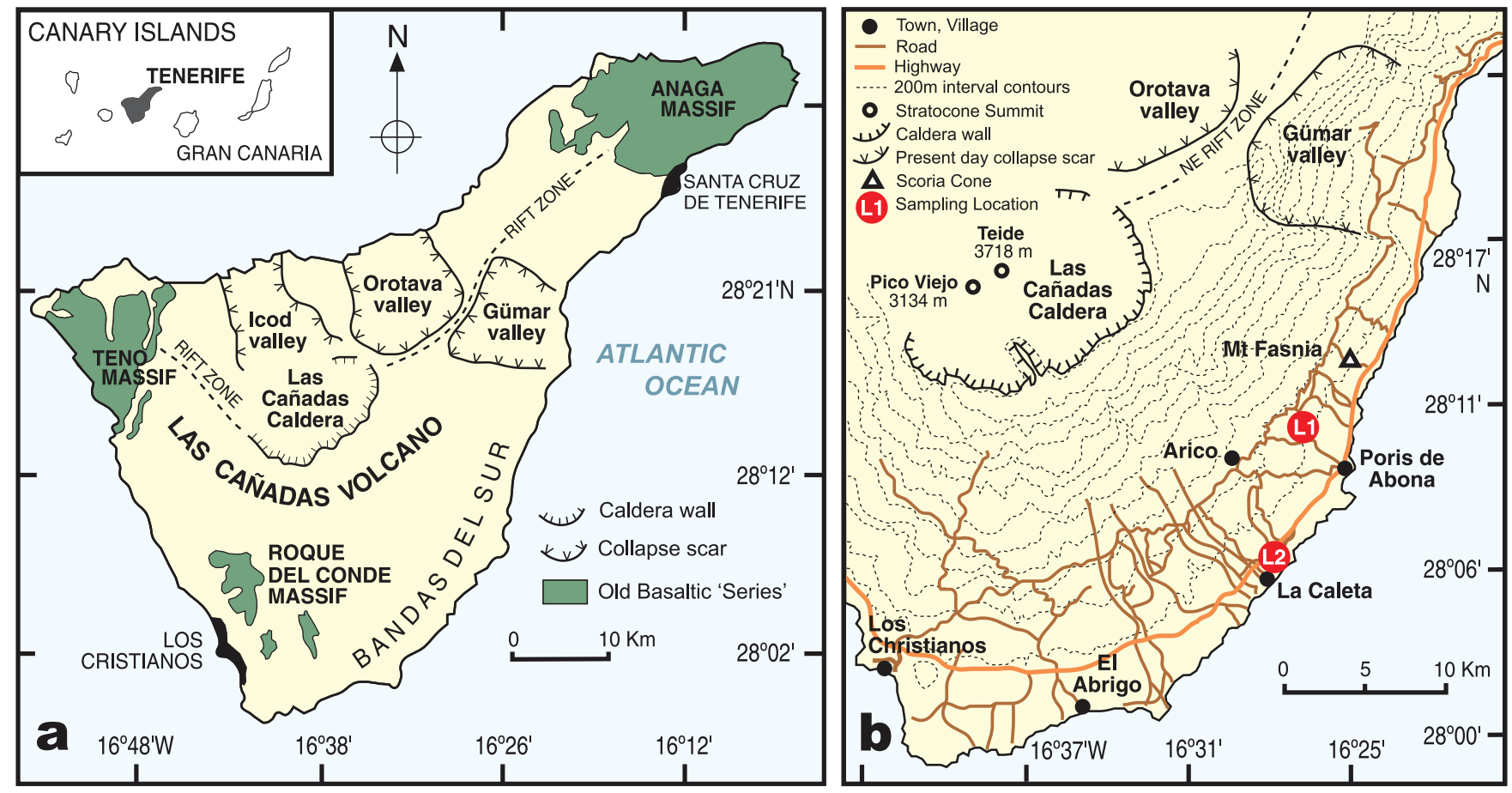

Figure $1 \mid$ Map of Tenerife showing locations of sampling sites. (a) Regional map of Tenerife showing major geological features and the location of the Bandas del Sur pyroclastic apron. Inset shows the position of Tenerife within the Canary Islands. (b) Detailed map of the Bandas del Sur Region, with sampling locations shown (modified after Ref. 1).
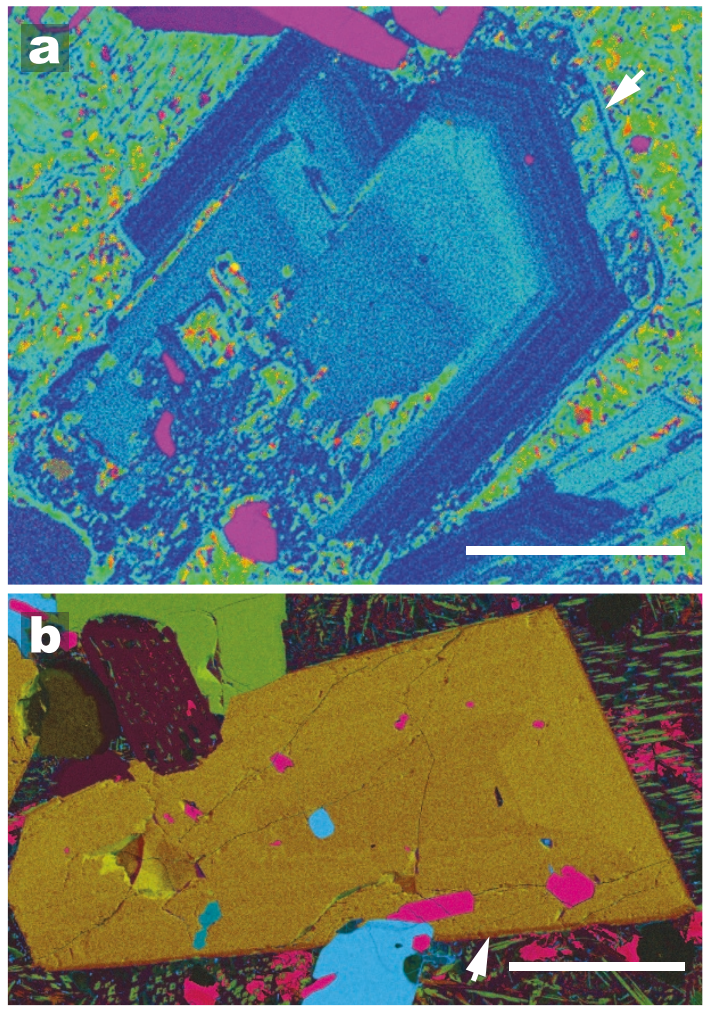

Figure $2 \mid$ Three-component electron microprobe element maps of zoned cumulus phases. (a) Variation in $\mathrm{Na}: \mathrm{Ca}: \mathrm{K}$ across a plagioclase cumulus crystal from the La Caleta Formation; note that lighter blue colours represent more albitic compositions. (b) Variation in $\mathrm{Mg}: \mathrm{Fe}: \mathrm{Ca}$ across a clinopyroxene cumulus crystal from the Fasnia Formation; note that darker orange colours represent more Fe-rich compositions. Colours are qualitative within each image and cannot be compared. Arrows highlight evolved rim zones at the crystal exteriors. Scale bar is $500 \mu \mathrm{m}$ on both images. regions of interstitial melt. A key feature of both the plagioclase and clinopyroxenes adjacent to this melt is a thin, optically bright zone $(<40 \mu \mathrm{m}$ wide) at the crystal rim (Fig. 2$)$.

\section{Results}

Major element concentrations of minerals vary in response to both melt composition and magma chamber conditions including pressure, temperature, volatile content and oxygen fugacity $\left(\mathrm{fO}_{2}\right)^{12}$. However, trace element concentrations are almost entirely a function of melt composition and are largely independent of changes in intensive parameters ${ }^{11}$. With the exception of rare patchy crystals, concentric zonation is evident (Fig. 2), implying little alteration by post-crystallization diffusion ${ }^{12}$. Within crystal mantles, compositions oscillate (Fig. 3), but zonation generally shows increasing $\mathrm{An} \#(\mathrm{Ca} /(\mathrm{Ca}+\mathrm{Na}) \times 100)$ in plagioclase, and either flat or slightly increasing $\mathrm{Mg} \#(\mathrm{Mg} /(\mathrm{Mg}+\mathrm{Fe}) \times 100)$ in clinopyroxene towards the outer rim (i.e. reverse zoning). This is also reflected in trace element transects by increasing $\mathrm{FeO}$ in plagioclase (Fig. 3). However, the most striking feature of the cumulus zoning is a sharp decrease in plagioclase An\# and clinopyroxene Mg\# at the rims of these crystals, with a corresponding drop in $\mathrm{Fe}$ content and $\mathrm{Al} / \mathrm{Ti}$ over the same distance.

In plagioclase, An\# correlates positively with melt temperature and $\mathrm{H}_{2} \mathrm{O}$ content, with changes in chamber pressure exerting only a minor control $^{13}$. Additionally, fluctuations in clinopyroxene Mg\# can occur in response to changes in melt $\mathrm{fO}_{2}$ (Ref. 14). Therefore, the oscillatory major element zoning may result from closed system processes, including crystal movement along thermal or compositional gradients, or open system processes, such as magmatic recharge ${ }^{11,13}$. However, the large magnitude changes in An\# and Mg\# approaching the rim of the cumulate minerals are unlikely to result from variations in intensive parameters alone ${ }^{12}$, and are more consistent with a sudden switch to a more evolved (felsic) melt composition.

As a trace element in plagioclase, Sr correlates negatively with An\# through the crystal mantles (Fig. 3). Although bulk melt composition may influence plagioclase-melt Sr partitioning, particularly in more evolved systems ${ }^{10,13}$, the dominant control on $\mathrm{Sr}$ is its increasing 

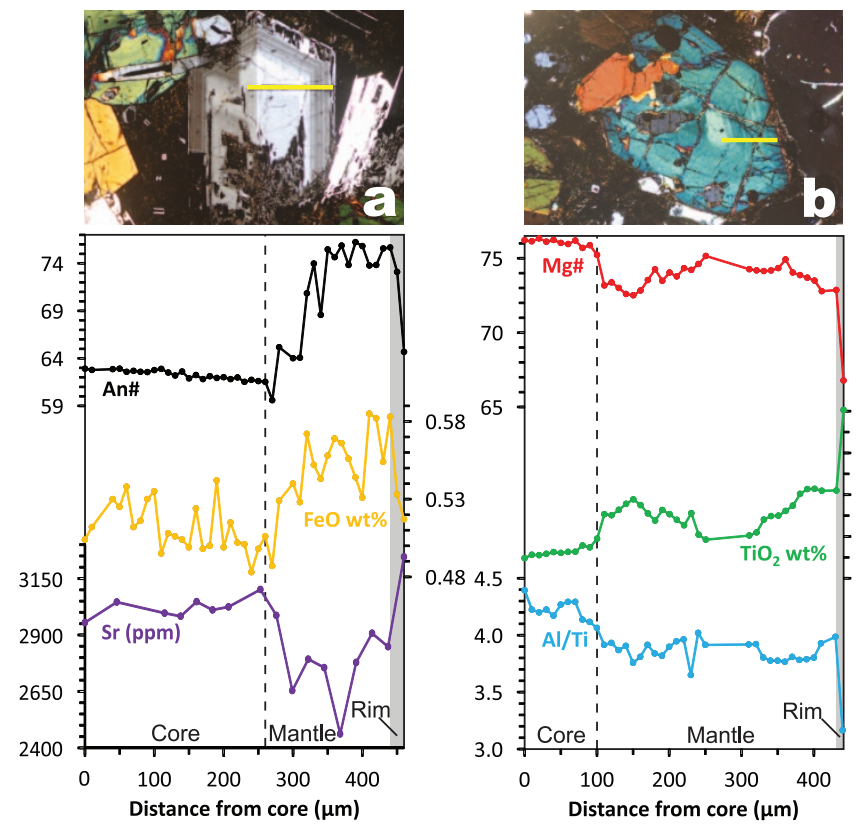
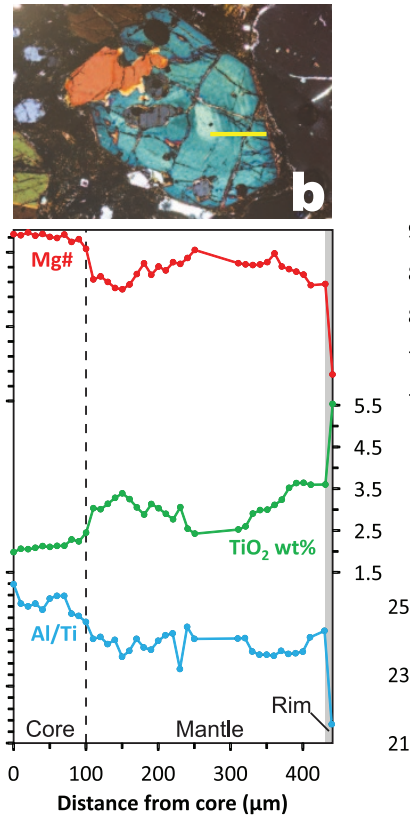
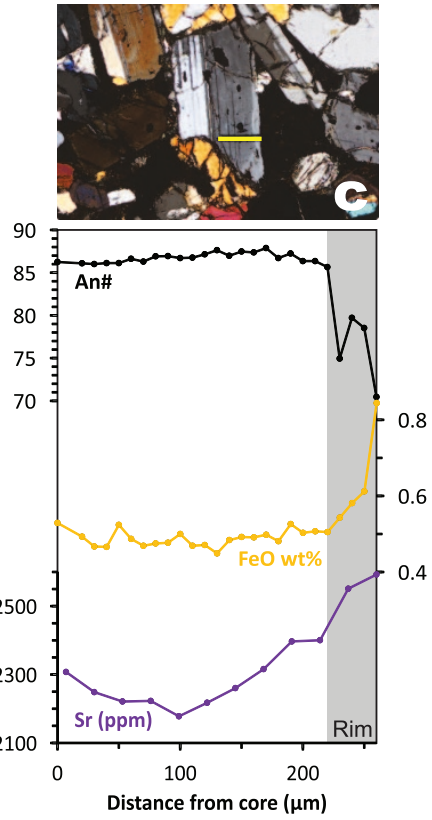

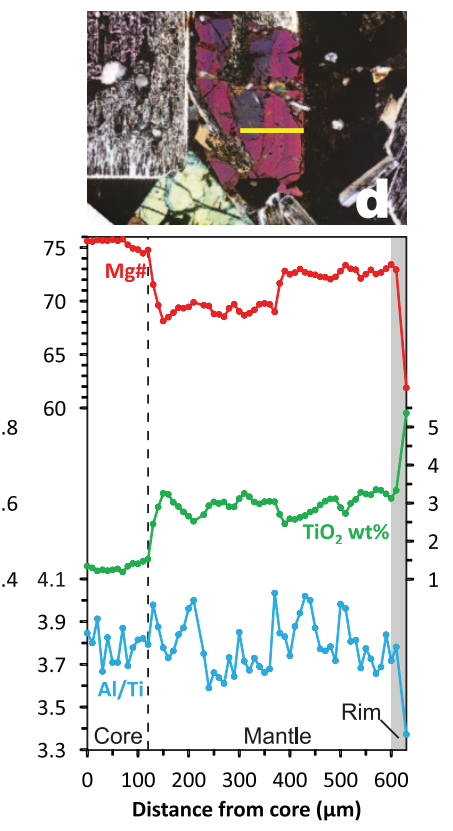

Figure $3 \mid$ Compositional profiles across representative plagioclase and clinopyroxene cumulus phases. (a) plagioclase and (b) clinopyroxene crystals from the La Caleta Formation, (c) plagioclase crystal from the Poris Formation, (d) clinopyroxene crystal from the Fasnia Formation. Photomicrograph images above the compositional profiles show optical zoning and position of compositional transects, shown below, which were collected from core to rim. The boundary between core- and mantle-regions is shown with a dashed line, where applicable. The grey shading in compositional profiles highlights the evolved zone at the crystal rims.

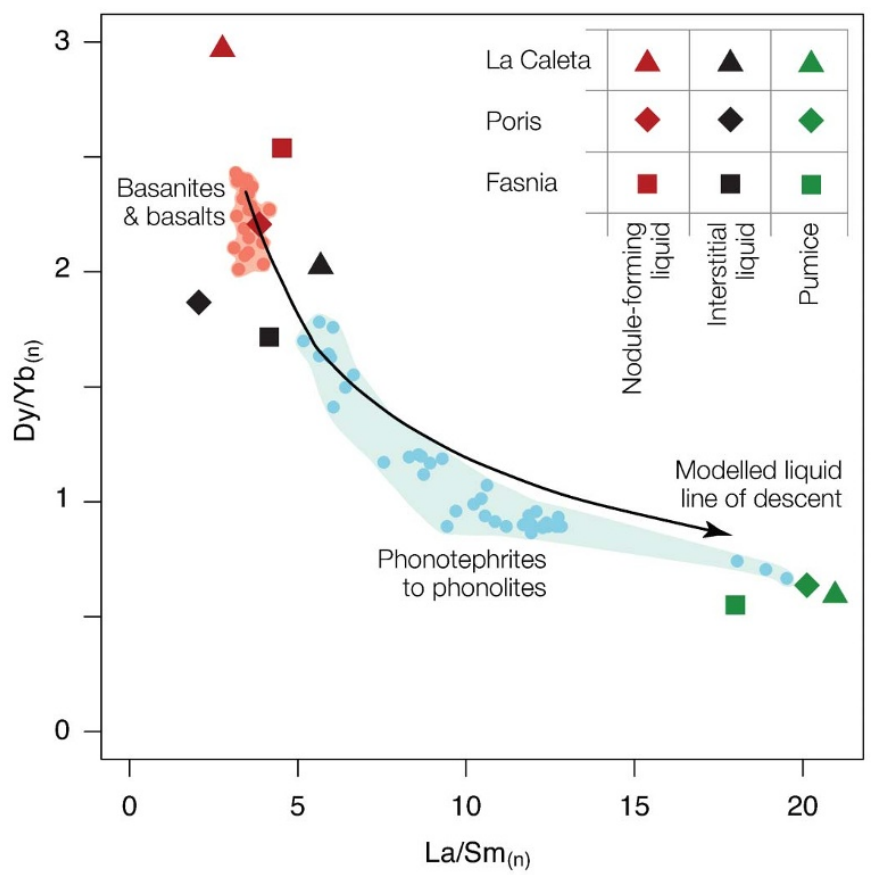

Figure 4 | Chondrite normalised rare earth element systematics of the Las Cañadas volcanics. Rare earth data are shown for: 1 . Nodule forming liquids (calculated to be in equilibrium with the bulk cumulus phases, excluding rim), 2. Groundmass material, representing the final interstitial liquid, and 3. Juvenile pumice. Each of these categories was measured for the La Caleta, Poris and Fasnia Formations. For comparison, Tenerifian basanites-basalts and phonotephrites-phonolites are plotted as the pink and blue data fields respectively. Evolution of Tenerifian liquids is shown as the black line. All data were normalised using the $\mathrm{C} 1$ chondrite in ref. 38 . Details of the data sources and modelling are presented in the methods section. compatibility in plagioclase with decreasing $A n \#^{15}$. Thus, the observed Sr zonation pattern is predicted by its changing partition coefficient, in response to this crystal-chemical control. In contrast, melt composition has the greatest effect on plagioclase Fe content ${ }^{13}$. This is known to increase with melt $\mathrm{fO}_{2}$ (ref. 16) and correlates negatively with temperature and $\mathrm{An} \#^{13,17}$. However, within the oscillatory zoned plagioclase mantles, An\# correlates positively with $\mathrm{FeO}$ (Fig. 3). As such, An-content and temperature may not have had a large influence on the $\mathrm{Fe}$ content of plagioclase. $\mathrm{fO}_{2}$-induced variations in plagioclase-liquid $\mathrm{Fe}$ partitioning are also unlikely to have significantly influenced Fe zoning, as this can not simply result in the positive correlation between $\mathrm{An \#}$ and $\mathrm{FeO}$. Variations in $\mathrm{FeO}$ are more readily explained by changes in melt composition resulting from repeated recharge of the fractionating magma chamber.

Variation in $\mathrm{Al} / \mathrm{Ti}$ is a useful indicator of melt evolution in Cr-deficient clinopyroxene crystals ${ }^{18}$. While $\mathrm{Al}$ and $\mathrm{Ti}$ concentrations may be affected by temperature, pressure and rate of crystal growth ${ }^{19}$, the Al/Ti ratio more strongly reflects changes in melt composition ${ }^{14}$. A minor increase in clinopyroxene $\mathrm{Al} / \mathrm{Ti}$ with temperature may occur due to the stronger partitioning of both $\mathrm{Al}^{I V}$ and $\mathrm{Al}^{V I 19}$. Although temperature fluctuations could cause the positive correlation between $\mathrm{Al} / \mathrm{Ti}$ and Mg\# observed within oscillatory zoned clinopyroxene mantles (Fig. 3), Ti concentration also shows a well-defined anticorrelation with Mg\#, which cannot result from variations in temperature alone ${ }^{19}$. Variable pressure is also an unlikely explanation for oscillatory $\mathrm{Al} / \mathrm{Ti}$ zoning, as closed system convection would only cause small pressure changes $(<1 \mathrm{~kb})^{20}$. Increased crystal growth rates relate to the degree of undercooling and correlate positively with $\mathrm{Al}$ and $\mathrm{Ti}^{21}$. This could explain the anti-correlation between $\mathrm{Ti}$ concentration and $\mathrm{Mg \#}$, so increased growth rates cannot be fully discounted as the cause of chemical Al/Ti zonation. However, all the clinopyroxenes exhibit concentric, rather than hourglass zoning, which would be expected if growth rate strongly influenced chemical zonation ${ }^{21}$. As such, clinopyroxene trace element zoning more likely records changes in melt composition.

Concordance of the plagioclase and clinopyroxene zoning patterns through the mantles of the cumulate phases is found in each 

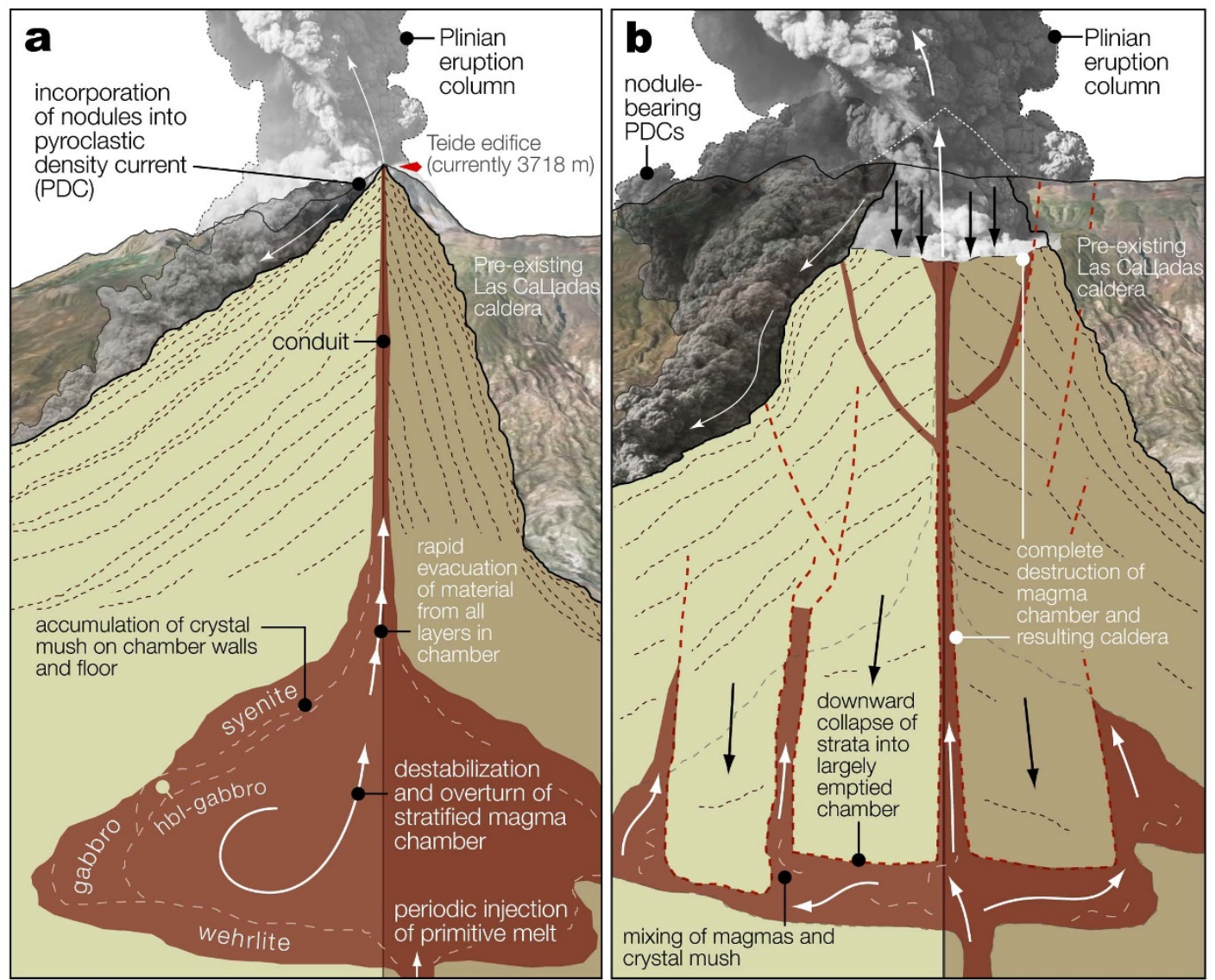

Figure $5 \mid$ Schematic diagram showing the repeating development of the Las Cañadas magma chamber. (a) Explosive eruption of the Las Cañadas volcano is triggered by destabilisation of the stratified magma chamber. (b) Incorporation of nodules from all magma chamber units into major pyroclastic density currents ${ }^{1}$ and resulting caldera collapse.

of the ignimbrite units. This is consistent with a fractionating magma chamber, periodically refilled by more primitive melt, rather than fluctuations in parameters such as pressure and temperature (e.g. refs. 22, 23). Petrological evidence, such as sieve textured plagioclase phenocrysts, compositionally distinct phenocryst cores and overgrowth mantles also suggest that open system mixing occurred during chamber development ${ }^{24}$. However, elemental oscillations cannot be correlated between crystals, indicating these events did not affect the whole chamber equally.

Changes in trace element concentrations accompany major element variations observed at crystal rims. In one plagioclase (La Caleta), the drop in An\# at the rim correlates with a substantial ( $\leq$ $11 \%)$ decrease in $\mathrm{FeO}$ concentration. This suggests that the rim zone reflects a significant change in melt composition, with lower $\mathrm{FeO}$ and An\# indicative of crystallisation from a more evolved liquid. In contrast, rim zones in other plagioclase crystals from the three ignimbrites show an increase in $\mathrm{FeO}$ concentration, mirroring the drop in An\#. This can be explained by cooling and rapid crystal growth, potentially accompanied by an increase in melt $f \mathrm{O}_{2}$, associated with a change to more evolved melt compositions. During rapid crystal growth, a chemical boundary layer, enriched in plagioclase incompatible elements such as $\mathrm{Fe}$, may form at the crystal-melt interface ${ }^{13}$. Although such kinetic effects could contribute to the high Fe concentrations at crystal rims, they cannot account for the concurrent drop in An\#. Contrasting $\mathrm{Fe}$ enrichment and depletion trends observed within rims of different plagioclase crystals are likely to result from varying degrees of undercooling. Both require a significant change in melt composition, regardless of the concentration shift direction. A large drop in $\mathrm{Al} / \mathrm{Ti}$ accompanies the decrease in $\mathrm{Mg \#}$ at the rim of most clinopyroxene phenocrysts analysed in this study and is taken as a further indication of a large-scale change in melt chemistry.

To test if the interstitial melt is in equilibrium with Tenerifian basaltic liquids or more evolved phonolitic compositions, we recovered and analysed interstitial material from nodules in each unit. Figure 4 shows that these interstices are displaced towards more phonolitic compositions relative to the liquids in equilibrium with the cumulus crystal-forming melts (excluding rims). As such, the "frozen" final liquids within these cumulates confirm that mixing occurred between phonolitic and basaltic magmas before each eruption.

\section{Discussion}

Rim zones are thin $(<40 \mu \mathrm{m})$, thus final growth is likely to represent only a brief period prior to eruption, probably on the order of $7-132$ days ${ }^{25}$. Low An\# and Mg\# in these rims suggests final growth in the presence of a significantly more evolved liquid, and the sharpness of this change precludes normal fractional crystallization. This is supported by the presence of an intercumulus liquid within the final "frozen" nodule, which has a more evolved composition than the liquid from which the cumulus phases crystallised. Two scenarios could explain the observed zonation: (1) The magma chamber was recharged with felsic melt, sourced from a separate, more evolved chamber. This has been recorded elsewhere ${ }^{26}$ but on Tenerife would require a third magma reservoir, separate to the Las Cañadas chamber and the source of mafic recharge magma; or (2) The stratified magma chamber became destabilised, causing mixing between evolved material close to the chamber roof with primitive material at the base (Fig. 5) ${ }^{27}$. Such an overturn may be driven by heating at the base of the magma chamber ${ }^{28}$, sinking of cold, dense plumes from an 
upper cupola layer ${ }^{10}$ or cooling and de-volatilisation of mafic magma close to the boundary with the overlying felsic material causing a density decrease ${ }^{29}$. Pre-eruptive mixing scenarios are supported by the presence of banded pumice within each formation ${ }^{1}$.

Similar evolved rims have been identified within phenocrysts from Tenerifian lavas, and these have been related to overturn of a stratified magma chamber ${ }^{10}$. The lack of any well-defined resorption surface between the rim and mantle suggests rim growth did not involve a significant change in magmatic temperature, so the eruption cannot easily be explained by felsic recharge ${ }^{10}$. Cumulate crystals analysed in this study also lack a clear resorption surface between the oscillatory mantle and rim zone and testify to a similar overturnmixing scenario. Furthermore, there is a lack of evidence for two substantial, high-level, evolved magma chambers coexisting between Plinian eruptions.

Multiple Plinian eruptions punctuated the volcanic development of Tenerife through the Quaternary, separated by quiescent periods ranging between $10 \mathrm{ka}$ and $300 \mathrm{ka}$. Approximately $170 \mathrm{ka}$ has elapsed since the last Plinian eruption, but this may be irrelevant if magmatic systems can reach critical eruptive states within decades ${ }^{30}$. Regardless of the timescales, the pre-climactic phase of magma chamber development appears to be consistent and systematic. Large-scale felsic-mafic magma interaction, preserved in partially developed crystal cumulates, appears to be the repeating trigger for destruction of the Las Cañadas magma chamber.

\section{Methods}

Electron microprobe analysis. Mineral major element compositions, plagioclase $\mathrm{FeO}$ and clinopyroxene $\mathrm{TiO}_{2}$ and $\mathrm{Al}_{2} \mathrm{O}_{3}$ concentrations were determined using a Cameca SX-100 five spectrometer electron microprobe in Earth and Environmental Science at the Open University, operating in wavelength-dispersion mode. All analyses were collected using a $20 \mathrm{kV}$ accelerating voltage and $20 \mathrm{nA}$ beam current. Measurements were made along a linear transect outwards from the crystal cores, with a $10 \mu \mathrm{m}$ beam diameter. Count times range between 20 and 80 s per element. Calibration standards include: jadeite $(\mathrm{Na})$, bustamite $(\mathrm{Ca})$, hematite $(\mathrm{Fe})$, forsterite $(\mathrm{Mg}), \mathrm{K}$-feldspar $(\mathrm{Al})$ and rutile $(\mathrm{Ti})$. Relative reproducibility estimates (2 sd) obtained from repeat analysis of a kaersutite reference material are $\leq \pm 1 \%(\mathrm{CaO})$, $\leq \pm 2 \%\left(\mathrm{MgO}, \mathrm{FeO}, \mathrm{Al}_{2} \mathrm{O}_{3}\right), \leq 3 \%\left(\mathrm{TiO}_{2}\right)$ and $\leq 5 \%\left(\mathrm{Na}_{2} \mathrm{O}_{3}\right)$.

Solution ICP-MS analysis. Juvenile pumice and intercumulus material were analysed for trace elements by inductively coupled plasma-mass spectrometry (ICPMS), using a Thermo X-series instrument in Ocean and Earth Science at the University of Southampton. Following $\mathrm{HF}$ and $\mathrm{HNO}_{3}$ digestion, samples were diluted by 2000-4000 and introduced via a microconcentric nebuliser. REE ratio precision is estimated to be better than $2 \%$ relative ( $2 \mathrm{sd}$ ) based on repeat analyses of rock standard JB-2.

\section{Laser ablation ICP-MS analysis. Plagioclase Sr and clinopyroxene REE} concentrations were determined using a Thermo X-Series II ICP-MS interfaced with a New Wave 193 excimer laser ablation system in Ocean and Earth Science at the University of Southampton. Typically measurements were conducted using a $5 \mathrm{~Hz}$ laser repetition rate with an $85 \%$ output. Count times were 20 s and an Ar carrier gas was used. Data were collected along linear transects, equivalent to the previous microprobe measurements, using a $20 \mu \mathrm{m}$ laser spot size, with a $3 \mu \mathrm{m}$ bridge between analyses. ICP-MS results were calibrated using NIST 610 and NIST 614 reference glasses. Relative reproducibility estimates for Sr, La, Sm, Dy and Yb are $\pm 3-4 \%$ (2 sd).

Data were excluded from both microprobe and LA-ICP-MS transects where analyses sampled inclusions or cracks within crystals. Additionally, points were discarded at the crystal rims where results showed evidence for any incorporation of intercumulus material.

Crystal fractionation modeling. A liquid evolution curve for the Tenerife alkaline magmas was calculated using a starting composition of basaltic lava DH97-28 $\mathrm{A}^{31}$. Liquids were calculated using the modal assemblages of basaltic, phonotephrite and phonolite lavas of Ablay et al. ${ }^{32}$ and the partition coefficients of Fujimaki et al. ${ }^{33}$, Fujimaki $^{34}$, Neuman ${ }^{35}$, and Nielsen et al. ${ }^{36}$. An initial $60 \%$ crystallisation used an assemblage with modal fractions olivine: clinopyroxene: amphibole: magnetite: apatite $=0.296: 0.561: 0.006: 0.115: 0.012$. The final liquid of this stage was then crystallised by a further $40 \%$ using olivine: clinopyroxene: plagioclase: magnetite: apatite $=0.050: 0.589: 0.198: 0.146: 0.016$. Subsequently, this liquid was crystallised by $50 \%$ using olivine: clinopyroxene: plagioclase: amphibole: magnetite: apatite $=$ 0.016: 0.190: 0.334: 0.295: 0.138: 0.047.

Data sources for Las Cañadas volcanics. For comparison with our measured data we have compiled rare earth element data for the Las Cañadas volcanics (Fig. 4), throughout the explosive phase of Tenerifian development. Samples include lavas, dykes and explosive ejecta which were sourced from the Bandas del Sur region and the Las Cañadas caldera wall. They are grouped according to their major element composition (i.e. primitive and evolved). Data sources are as follows:

Basalts and basanites: data sourced from ref. 6,23,31

Phonotephrites to phonolites: data sourced from ref. 23,31,37

1. Brown, R. J., Barry, T. L., Branney, M. J., Pringle, M. S. \& Bryan, S. E. The Quaternary pyroclastic succession of southeast Tenerife, Canary Islands: explosive eruptions, related caldera subsidence, and sector collapse. Geological Magazine 140, 265-288 (2003).

2. Bryan, S. E., Martí, J. \& Cas, R. Stratigraphy of the Bandas del Sur Formation: an extracaldera record of Quaternary phonolitic explosive eruptions from the Las Canadas edifice, Tenerife (Canary Islands). Geological Magazine 135, 605-636 (1998).

3. Ancochea, E., Fuster, J., Ibarrola, E., Cendrero, A., Coello, J., Hernan, F., Cantagrel, J. M. \& Jamond, C. Volcanic evolution of the island of Tenerife (Canary Islands) in the light of new K-Ar data. Journal of Volcanology and Geothermal Research 44(3-4), 231-249 (1990).

4. Martí, J., Mitjavila, J. \& Araña, V. Stratigraphy, structure and geochronology of the Las Cañadas caldera (Tenerife, Canary Islands). Geological Magazine 131(6), 715-727 (1994).

5. Ablay, G. \& Martí, J. Stratigraphy, structure, and volcanic evolution of the Pico Teide-Pico Viejo formation, Tenerife, Canary Islands. Journal of Volcanology and Geothermal Research 103(1-4), 175-208 (2000).

6. Bryan, S. E., Martí, J. \& Leosson, M. Petrology and Geochemistry of the Bandas del Sur Formation, Las Cañadas Edifice, Tenerife (Canary Islands). Journal of Petrology 43(10), 1815-1856 (2002).

7. Holness, M. B. \& Bunbury, J. M. Insights into continental rift-related magma chambers: Cognate nodules from the Kula Volcanic Province, Western Turkey. Journal of Volcanology and Geothermal Research 153(3-4), 241-261 (2006).

8. Tait, S. R., Wörner, G., Bogaard, P. V. D. \& Schmincke, H.-U. Cumulate nodules as evidence for convective fractionation in a phonolite magma chamber. Journal of Volcanology and Geothermal Research 37(1), 21-37 (1989).

9. Wolff, J. A. Crystallisation of nepheline syenite in a subvolcanic magma system: Tenerife, canary islands. Lithos 20(3), 207-223 (1987).

10. Triebold, S., Kronz, A. \& Wörner, G. Anorthite-calibrated backscattered electron profiles, trace elements, and growth textures in feldspars from the Teide-Pico Viejo volcanic complex (Tenerife). Journal of Volcanology and Geothermal Research 154(1-2), 117-130 (2006).

11. Ruprecht, P. \& Wörner, G. Variable regimes in magma systems documented in plagioclase zoning patterns: El misti stratovolcano and andahua monogenetic cones. Journal of Volcanology and Geothermal Research 165(3-4), 142-162 (2007).

12. Streck, M. J. Mineral textures and zoning as evidence for open system processes. Reviews in Mineralogy and Geochemistry 69(1), 595-622 (2008).

13. Ginibre, C., Wörner, G. \& Kronz, A. Minor- and trace-element zoning in plagioclase: implications for magma chamber processes at Parinacota volcano, northern Chile. Contributions to Mineralogy and Petrology 143, 300-315 (2002). 10.1007/s00410-002-0351-z.

14. Streck, M. J., Dungan, M. A., Malavassi, E., Reagan, M. K. \& Bussy, F. The role of basalt replenishment in the generation of basaltic andesites of the ongoing activity at Arenal volcano, Costa Rica: evidence from clinopyroxene and spinel. Bulletin of Volcanology 64, 316-327 (2002). 10.1007/s00445-002-0209-2.

15. Blundy, J. D. \& Wood, B. J. Crystal-chemical controls on the partitioning of sr and ba between plagioclase feldspar, silicate melts, and hydrothermal solutions. Geochimica et Cosmochimica Acta 55(1), 193-209 (1991).

16. Wilke, M. \& Behrens, H. The dependence of the partitioning of iron and europium between plagioclase and hydrous tonalitic melt on oxygen fugacity. Contributions to Mineralogy and Petrology 137, 102-114 (1999). 10.1007/s004100050585.

17. Bindeman, I. N., Davis, A. M. \& Drake, M. J. Ion microprobe study of plagioclasebasalt partition experiments at natural concentration levels of trace elements. Geochimica et Cosmochimica Acta 62(7), 1175-1193 (1998).

18. Streck, M. J., Dungan, M. A., Bussy, F. \& Malavassi, E. Mineral inventory of continuously erupting basaltic andesites at Arenal volcano, Costa Rica: implications for interpreting monotonous, crystal-rich, mafic arc stratigraphies. Journal of Volcanology and Geothermal Research 140(1-3), 133-155 (2005).

19. Adam, J. \& Green, T. The effects of pressure and temperature on the partitioning of $\mathrm{Ti}, \mathrm{Sr}$ and REE between amphibole, clinopyroxene and basanitic melts. Chemical Geology 117(1-4), 219-233 (1994).

20. Ginibre, C., Kronz, A. \& Wörner, G. High-resolution quantitative imaging of plagioclase composition using accumulated backscattered electron images: new constraints on oscillatory zoning. Contributions to Mineralogy and Petrology 142, 436-448 (2002). 10.1007/s004100100298.

21. Skulski, T., Minarik, W. \& Watson, E. B. High-pressure experimental traceelement partitioning between clinopyroxene and basaltic melts. Chemical Geology 117(1-4), 127-147 (1994).

22. O'Hara, M. J. Geochemical evolution during fractional crystallisation of a periodically refilled magma chamber. Nature 266(5602), 503-507, 04 (1977). 
23. Neumann, E.-R., Wulff-Pedersen, E., Simonsen, S. L., Pearson, N. J., Martí, J. \& Mitjavila, J. Evidence for fractional crystallization of periodically refilled magma chambers in Tenerife, Canary Islands. Journal of Petrology 40(7), 1089-1123 (1999).

24. Humphreys, M. C. S., Blundy, J. D. \& Sparks, R. S. J. Magma evolution and opensystem processes at Shiveluch Volcano: Insights from phenocryst zoning. Journal of Petrology 47(12), 2303-2334 (2006).

25. Larsen, J. F. Experimental study of plagioclase rim growth around anorthite seed crystals in rhyodacitic melt. American Mineralogist 90(2-3), 417-427 (2005).

26. de Silva, S., Salas, G. \& Schubring, S. Triggering explosive eruptions-The case for silicic magma recharge at Huaynaputina, southern Peru. Geology 36, 387-390 (2008)

27. Sparks, S. R. J., Sigurdsson, H. \& Wilson, L. Magma mixing: a mechanism for triggering acid explosive eruptions. Nature 267, 315-318 (1977).

28. Couch, S., Sparks, R. S. J. \& Carroll, M. R. Mineral disequilibrium in lavas explained by convective self-mixing in open magma chambers. Nature $\mathbf{4 1 1}$, 1037-1039 (2001).

29. Huppert, H. E., Sparks, R. S. J. \& Turner, J. S. Effects of volatiles on mixing in calcalkaline magma systems. Nature 297(5867), 554-557 (1982).

30. Druitt, T. H., Costa, F., Deloule, E., Dungan, M. \& Scaillet, B. Decadal to monthly timescales of magma transfer and reservoir growth at a caldera volcano. Nature 482(7383), 77-80 (2012).

31. Wolff, J., Grandy, J. \& Larson, P. Interaction of mantle-derived magma with island crust? Trace element and oxygen isotope data from the Diego Hernandez Formation, Las Cañadas, Tenerife. Journal of Volcanology and Geothermal Research 103(1-4), 343-366 (2000).

32. Ablay, G. J., Carroll, M. R., Palmer, M. R., Martí, J. \& Sparks, R. S. J. Basanitephonolite lineages of the Teide-Pico Viejo Volcanic Complex, Tenerife, Canary Islands. Journal of Petrology 39(5), 905-936 (1998).

33. Fujimaki, H., Tatsumoto, M. \& Aoki, K.-i. Partition coefficients of Hf, Zr, and REE between phenocrysts and groundmasses. J. Geophys. Res. 89(S2), B662-B672 (1984).

34. Fujimaki, H. Partition coefficients of Hf, Zr, and REE between zircon, apatite, and liquid. Contributions to Mineralogy and Petrology 94, 42-45 (1986). 10.1007/ BF00371224

35. Neumann, E.-R., Wulff-Pedersen, E., Pearson, N. J. \& Spencer, E. A. Mantle xenoliths from Tenerife (Canary Islands): Evidence for reactions between mantle peridotites and silicic carbonatite melts inducing ca metasomatism. Journal of Petrology 43(5), 825-857 (2002).

36. Nielsen, R. L., Gallahan, W. E. \& Newberger, F. Experimentally determined mineral-melt partition coefficients for Sc, Y and REE for olivine, orthopyroxene, pigeonite, magnetite and ilmenite. Contributions to Mineralogy and Petrology 110, 488-499 (1992). 10.1007/BF00344083.

37. Bryan, S. E. Petrology and geochemistry of the Quaternary caldera-forming, phonolitic Granadilla Eruption, Tenerife (Canary Islands). Journal of Petrology 47(8), 1557-1589 (2006).

38. Sun, S.-s. \& McDonough, W. F. Chemical and isotopic systematics of oceanic basalts: implications for mantle composition and processes. Geological Society, London, Special Publications 42(1), 313-345 (1989).

\section{Acknowledgements}

We are grateful to A. Milton and A. Tindle for their assistance with the ICP-MS and microprobe respectively. We thank J. Blundy and M. Lane for helpful discussions, and acknowledge M. Cassidy for providing field assistance. K. Davis is thanked for drafting the maps shown in Figure 1.

\section{Author contributions}

R.T. directed the research; M.S., R.T. and T.G. carried out the fieldwork and sampling; M.S. and R.T. carried out the analytical work and modelling. All authors wrote the paper, drafted the figures, discussed the results and contributed to the final manuscript.

\section{Additional information}

Competing financial interests: The authors declare no competing financial interests.

License: This work is licensed under a Creative Commons

Attribution-NonCommercial-NoDerivative Works 3.0 Unported License. To view a copy of this license, visit http://creativecommons.org/licenses/by-nc-nd/3.0/

How to cite this article: Stock, M.J., Taylor, R.N. \& Gernon, T.M. Triggering of major eruptions recorded by actively forming cumulates. Sci. Rep. 2, 731; DOI:10.1038/srep00731 (2012) 


\section{SUBJECT AREAS:} GEOCHEMISTRY PETROLOGY VOLCANOLOGY ENVIRONMENTAL SCIENCES SCIENTIFIC REPORTS: $2: 731$ DOI: 10.1038/srep00731 (2012)

Published: 12 October 2012 Updated: 25 March 2013
ERRATUM: Triggering of major eruptions recorded by actively forming cumulates Michael J. Stock, Rex N. Taylor \& Thomas M. Gernon

Due to a technical error, the corresponding author is incorrectly given as Thomas M. Gernon rather than Rex N. Taylor in the HTML version of this Article. For correspondence and requests for materials, please contact Rex N. Taylor (rex@noc.soton.ac.uk). This error has now been updated in the original Article. 